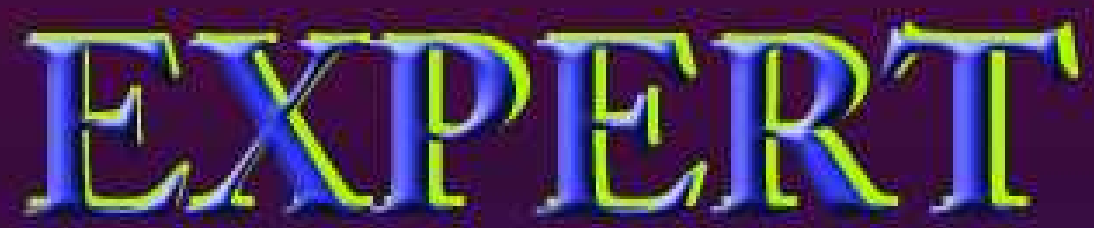

Jurnal Sistem Informasi

PERANCANGAN PROTOTYPE TEKNOLOGI SMART BUILDING MENGGUNAKAN ARDUINO BERBASIS WEB SERVER UNTUK MENDUKUNG PEMBANGUNAN PROPINSI LAMPUNG MENUJU PROGRAM LAMPUNG "SMART CITY"

Budi Usmanto, Tri Susilowati

SISTEM PENDUKUNG KEPUTUSAN PERANGKINGAN SEKOLAH MENENGAH KEJURUAN (SMK) DI KABUPATEN PRINGSEWU MENGGUNAKAN METODE WEIGHTED PRODUCT (WP)

Oktafianto, Elisabet Yunacti Anggracni, Suyono

OTORISASI PENGGUNA LABORATORIUM IBI DARMAJAYA BERBASIS CLIENT SERVER

Hendra Kurniawan, Hermanto

SISTEM PENDUKUNG KEPUTUSAN BERBASIS ANALYTICAL HIERARKHI PROCESS UNTUK PENENTUAN PENGISIAN JABATAN

Fenty Ariani

SEBARAN MENARA TELEKOMUNIKASI SELULER BERSAMA BERBASIS GIS (GEOGRAPHIC INFORMATION SYSTEM)

DI WILAYAH KABUPATEN LAMPUNG TENGAH

Taqwan Thamrin, Wiwin Susanty

AUTHENTIFIKASI LOGIN USER PADA PERANGKAT LUNAK MENGGUNAKAN ARDUINO DAN ENKRIPSI AES 256

Apri Triansah

ISSN : 2088-5555

$$
\text { Write To Be Experte }
$$




\section{Expert}

Jurnal Manajemen Sistem Informasi dan Teknologi

Volume 07, Nomor 02, Desember 2017

\begin{tabular}{|c|c|}
\hline Judul & Hal \\
\hline $\begin{array}{lllr}\text { PERANCANGAN } & \text { PROTOTYPE } & \text { TEKNOLOGI } & \text { SMART } \\
\text { BUILDING } & \text { MENGGUNAKAN ARDUINO BERBASIS WEB } \\
\text { SERVER } & \text { UNTUK } & \text { MENDUKUNG PEMBANGUNAN } \\
\text { PROPINSI LAMPUNG } & \text { MENUJU PROGRAM LAMPUNG } \\
\text { "SMART CITY" } & & & \\
\end{array}$ & $57-65$ \\
\hline $\begin{array}{l}\text { SISTEM PENDUKUNG KEPUTUSAN PERANGKINGAN } \\
\text { SEKOLAH MENENGAH KEJURUAN (SMK) DI KABUPATEN } \\
\text { PRINGSEWU MENGGUNAKAN METODE WEIGHTED } \\
\text { PRODUCT (WP) }\end{array}$ & $66-71$ \\
\hline $\begin{array}{l}\text { OTORISASI } \quad \text { PENGGUNA } \quad \text { LABORATORIUM } \\
\text { DARMAJAYA BERBASIS CLIENT SERVER }\end{array}$ & $72-76$ \\
\hline $\begin{array}{l}\text { SISTEM PENDUKUNG KEPUTUSAN BERBASIS } \\
\text { ANALYTICAL HIERARKHI PROCESS UNTUK PENENTUAN } \\
\text { PENGISIAN JABATAN }\end{array}$ & $77-82$ \\
\hline $\begin{array}{l}\text { SEBARAN MENARA TELEKOMUNIKASI SELULER } \\
\text { BERSAMA BERBASIS GIS (GEOGRAPHIC INFORMATION } \\
\text { SYSTEM) DI WILAYAH KABUPATEN LAMPUNG TENGAH }\end{array}$ & $83-89$ \\
\hline $\begin{array}{l}\text { AUTHENTIFIKASI LOGIN USER PADA PERANGKAT } \\
\text { LUNAK MENGGUNAKAN ARDUINO DAN ENKRIPSI AES } \\
256\end{array}$ & $90-95$ \\
\hline
\end{tabular}

Fakultas Ilmu Komputer

Universitas Bandar Lampung

\begin{tabular}{|c|c|c|c|c|}
\hline \multirow{2}{*}{ JMSIT } & Volume 07 & Nomor 02 & Lampung, Desember & ISSN \\
& & 2017 & $2088-5555$ \\
\hline
\end{tabular}




\section{TIM PENYUNTING}

\section{Penanggung Jawab}

Ahmad Cucus, S.Kom., M.Kom.

Ketua Tim Redaksi:

Taqwan Thamrin, ST, M.Sc.

Penyunting Ahli (Mitra Bestari):

Mustofa Usman, Ph.D (Universitas Lampung)

Dra. Wamiliana, MA., Ph.D (Universitas Lampung)

Iing Lukman, M.Sc., Ph. D (Universitas Malahayati)

\section{Penyunting:}

Fenty Ariani, S.Kom, M.Kom

Robby Yuli Endra, S.Kom.,M.Kom

Ayu Kartika Puspa, S.Kom, M.TI

Erlangga, S.Kom, M.Kom

\section{Pelaksana Teknis:}

Dian Resha Agustina, S.Kom

\section{Alamat Penerbit/Redaksi:}

Pusat Studi Teknologi Informasi

Fakultas Ilmu Komputer

Universitas Bandar Lampung

Gedung Business Center Lt.2

Jl. Zainal Abidin Pagar Alam No. 26

Bandar Lampung

Email: Journal.expert@ubl.ac.id 


\title{
SISTEM PENDUKUNG KEPUTUSAN \\ BERBASIS ANALYTICAL HIERARKHI PROCESS UNTUK PENENTUAN PENGISIAN JABATAN
}

\author{
Fenty Ariani \\ Fakultas Ilmu Komputer \\ Program Studi Sistem Informasi \\ Universitas Bandar Lampung \\ Jl. ZA Pagar Alam No 26 Labuhan Ratu Bandar Lampung \\ fenty.ariani@ubl.ac.id
}

\begin{abstract}
Abstrak
Pegawai adalah bagian yang sangat penting bagi perusahaan untuk mencapai tujuannya. Sebelumnya Pengisian Jabatan dilakukan secara Manual, dengan mempertimbangkan kerja dan hasil wawancara yang dilakukan oleh Manajer Cabang, hal ini seringkali menimbulkan penilaian yang kurang obyektif . Tujuan dari pembuatan sistem ini dalam rangka menciptakan sistem yang ditujukan untuk menilai Pegawai yang memenuhi syarat untuk mengisi posisi dengan menggunakan Metode AHP. Sistem pendukung keputusan berdasarkan metode AHP telah memberikan hasil bahwa Pegawai yang mungkin memenuhi persyaratan untuk mengisi posisi yang kosong sesuai dengan kriteria yang telah ditentukan. Berdasarkan perhitungan bahwa untuk hasil yang diperoleh memiliki tingkat error menggunakan perhitungan AHP 0,001115 atau memiliki akurasi 99,89\%. Dengan demikian, dapat disimpulkan bahwa perhitungan dengan menggunakan metode AHP lebih akurat.
\end{abstract}

Kata kunci : Sistem Pendukung Keputusan, AHP.

\section{PENDAHULUAN \\ 1.1 Latar Belakang}

Pada sebuah perusahaan, pegawai merupakan bagian yang sangat penting bagi perusahaan dalam mencapai tujuan perusahaan, maka dari itu perusahaan dalam proses penerimaan pegawai mempunyai kriteria-kriteria khusus agar nantinya sesuai dengan kebutuhan perusahaan. Selain melakukan penerimaan pegawai, perusahaan juga terkadang melakukan proses pengisian jabatan, dimana hal ini dilakukan jika terdapat jabatan yang kosong. Pengisian jabatan yang ada pada perusahaan masih dilakukan secara manual yaitu dengan mempertimbangkan masa kerja dan hasil dari interview yang dilakukan oleh Branch Manager, sehingga menimbulkan penilaian yang kurang objektif.

AHP (Analytical Hierarkhi Process) pada dasarnya proses pengambilan keputusan adalah memilih suatu alternatif. Peralatan utama AHP adalah sebuah hierarki fungsional dengan input utamanya persepsi manusia. AHP memiliki banyak keunggulan dalam menjelaskan proses pengambilan keputusan. Salah satunya adalah dapat digambarkan secara grafis sehingga mudah dipahami oleh semua pihak yang terlibat dalam pengambilan keputusan. (Kusrini, 2007). Pada pemilihan pegawai yang akan mengisi jabatan yang kosong menggunakan 5 aspek penilaian yaitu : Kompetensi, Perilaku, Kepemimpinan, Prestasi Kerja dan Disiplin. Penelitian hanya dilakukan kepada Pegawai Internal Perusahaan.
Dengan dibangunnya sistem untuk menentukan pengisian jabatan yang kosong, maka diharapkan dapat membantu dalam menentukan calon pegawai untuk kemudian dapat mengisi kekosongan jabatan yang ada.

\subsection{Rumusan Masalah}

Berdasarkan latar belakang yang telah diuraikan diatas, maka peneliti merumuskan masalah yaitu: Apakah aplikasi sistem pendukung keputusan dapat digunakan sebagai alat bantu pengisian jabatan berbasis AHP?

\subsection{Tujuan Penelitian}

Berdasarkan pada permasalahan yang telah diuraikan sebelumnya, maka tujuan yang ingin dicapai dalam penelitian ini adalah sebagai berikut :

1. Membandingkan proses perhitungan dengan menggunakan metode AHP dengan perhitungan yang dilakukan secara manual dalam proses pengisian jabatan, sehingga dapat menghasilkan penilaian yang optimal dan akurat dalam memberikan penilaian.

2. Membangun sebuah aplikasi pendukung keputusan serta menerapkan metode AHP kedalam sebuah aplikasi pendukung keputusan.

\subsection{Manfaat Penelitian} berikut :
Adapun manfaat penelitian ini adalah sebagai 
1. Berdasarkan hasil dari penelitian akan membantu pengambil keputusan dalam memilih pegawai yang sesuai untuk mengisi jabatan yang kosong sesuai dengan kriteria jabatan.

2. Dengan adanya aplikasi ini nantinya diharapkan dapat memberikan informasi yang cepat, tepat dan akurat sesuai kebutuhan dalam membantu proses pengisian jabatan pegawai.

\section{LANDASAN TEORI}

\subsection{Ruang Lingkup Pengisian Jabatan}

Ruang lingkup pengisian jabatan pada Pada PT. Life Assurance di Bandar Lampung adalah :

1. Pengadaan (Procurement)

Proses penarikan, seleksi, penempatan, orientasi, dan induksi untuk mendapatkan pegawai baik kualitas maupun kuantitasnya sesuai dengan kebutuhan perusahaan.

\section{Penarikan (Recruiting)}

Kegiatan mencari dan mempengaruhi tenaga kerja agar mau melamar lowongan pekerjaan yang masih kosong di perusahaan.

Faktor-faktor yang mempengaruhi :

a. Balas jasa

b. Status Pegawai

c. Kesempatan promosi

d. Job specification

e. Metode penarikan

f. Penawaran tenaga kerja

Sumber-sumber penarikan :

a. Sumber Internal

Ditarik dari pegawai yang telah ada dalam perusahaan. Penarikan dilakukan dengan cara "mutasi atau transfer", baik sifatnya vertikal (promosi-demosi) maupun horizontal.

b. Sumber Eksternal

Mengisi lowongan jabatan yang kosong ditarik dari orang-orang diluar perusahaan.

\section{Seleksi (Selection)}

Serangkaian kegiatan yang dilaksanakan untuk memutuskan apakah seorang pelamar diterima/ditolak, tetap/tidaknya seorang pekerja ditempatkan pada posisi-posisi tertentu yang ada dalam organisasi.

\section{Penempatan (Placement)}

Kegiatan untuk menempatkan orang-orang yang telah lulus seleksi pada jabatan-jabatan tertentu sesuai dengan uraian pekerjaan dan klarifikasi-klarifikasi pekerjanya.

\section{Pemberhentian (Separation)}

Putusnya hubungan kerja seseorang karyawan dengan suatu perusahaan. Pemberhentian (PHK) ini disebabkan oleh keinginan perusahaan, keinginan karyawan, kontrak kerja habis, peraturan perburuhan, pensiun dan atau meninggal dunia.

\subsection{Prinsip dasar AHP}

Dalam menyelesaikan permasalahan denan AHP ada beberapa prinsip yang harus dipahami, diantaranya adalah :

\section{Membuat hierarki}

Sistem yang kompleks bisa dipahami dengan memecahnya menjadi elemen-elemen pendukung, menyusun elemen secara hierarki, dan menggabungkan atau mensistensinya.

Menurut (Suryadi K. d., 2002; Suryadi R. ) pada dasarnya langkah-langkah dalam metode AHP adalah sebagai berikut :

a. Mendefenisikan masalah dan menentukan solusi yang diinginkan.

b. Membuat struktur hirarki yang diawali dengan tujuan umun, dilanjutkan dengan kriteria-kriteria dan alternatif - alternatif pilihan yang diinginan di rangking.

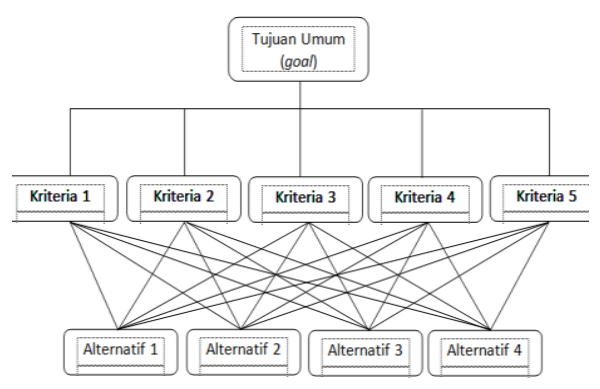

Gambar 1 Struktur Hirarki dalam AHP

c. Membuat Matriks perbandingan berpasangan yang menggambarkan zontribusi relatif atau pengaruh setiap elemen terhadap masing-masing tujuan dan kriteria yang setinggkat datanya. Perbandingan dilakukan berdasarkan " judgement" dari pengambil keputusan dengan menilai tingkat kepentingan suatu elemen di banding dengan elemen lainnya.

\section{Penilaian kriteria dan alternatif}

Kriteria dan alternatif dilakukan dengan perbandingan berpasangan. Menurut (Saaty, 1993) untuk berbagai persoalan, skala 1 sampai 9 adalah skala terbaik untuk mengekspresikan pendapat.

3. Syntheis of priority (menetukan prioritas) Untuk setiap kriteria dan alternatif, perlu dilakukan perbandingan berpasangan. Nilainilai perbandingan relatif dari seluruh alternatif kriteria bisa disesuaikan dengan judgement yang telah ditentukan untuk menghasilkan bobot dan prioritas. Bobot dan prioritas dihitung dengan manipulasi matriks atau melalui penyelesain persamaan matriks. 
4. Logical Consistency (Konsistensi Logis)

Konsistensi memilki dua makna. Petama, objek-objek yang serupa bisa dikelompokkan sesuai dengan keseragaman dan relevansi. Kedua, menyangkut tingkat hubungan antar objek yang didasarkan pada kriteria tertentu.

\subsection{Prosedur AHP}

Pada dasarnya, prosedur atau langkahlangkah dalam metode $A H P$ meliputi :

1. Mendefinisikan masalah dan menentukan solusi yang diinginkan lalu menyusun hierarki dari permasalahan yang ada.

2. Menentukan prioritas elemen.

3. Sintesis. Pertimbangan-pertimbangan terhadap perbandingan berpasangan disentesis untuk memperoleh keseluruhan prioritas.

4. Mengukur Konsistensi. Dalam pembuatan keputusan, penting untuk mengetahui seberapa baik konsistensi yang ada karena kita tidak menginginkan keputusan berdasarkan pertimbangan dengan konsistensi rendah.

5. Hitung konsistensi Index :

(CI) dengan rumus : $(\mathrm{CI})=\left(\lambda_{\text {maks-n }}\right) / \mathrm{n}$

dimana $\mathrm{n}=$ banyaknya elemen

6. Hitung Rasio Konsistensi/Consistency Ratio (CR) dengan rumus :

$$
\mathrm{CR}=\mathrm{CI} / \mathrm{RC}
$$

dimana $\quad \mathrm{CR}=$ Consistency Ratio

$\mathrm{CI}=$ Consistency Index

IR = Indeks Random Consistency

7. Memeriksa consistency hierarki.

\section{METODOLOGI PENELITIAN}

Metode penelitian ialah cara ilmiah untuk mendapatkan data dengan tujuan \& kegunaan tertentu (Sugiyono, 2010). Peneliti melakukan survei atau pengamatan langsung terhadap proses pengisian jabatan. Tahapan survei yang dilakukan adalah sebagai berikut :

1. Mewawancarai langsung ke bagian HRD perusahaan tentang proses pengisian jabatan.

2. Mencatat apa saja yang menjadi penilaian pada perusahaan terhadap proses pengisian jabatan.

Survei yang dilakukan menghasilkan informasi berupa kelemahan atau kekurangan yang terdapat pada sistem pengisian jabatan. Kekurangan dari sistem yang lama adalah sebagai berikut :

1. Penilaian yang dilakukan hanya terbatas pada masa kerja dan wawancara dengan calon pegawai yang dilakukan oleh Branch Manager.

2. Penilaian yang dilakukan dalam proses pengisian jabatan dirasa kurang optimal dan akurat.

Hasil survei yang didapat akan digunakan sebagai acuan dalam menentukan atau menganalisis kebutuhan sistem.

\subsection{Use Case Diagram}

Use case adalah deskripsi fungsi dari sebuah system dari perspektif pengguna (Munawar, 2005). Use case dapat bekerja dengan cara mendeskripsikan tipikal interaksi user sesbuah system dengan systemnya sendiri melalui sebuah cerita bagaimana sebuah system dipakai. Gambaran atau model dari pembuatan system pengisian jabatan berbasis AHP ini dapat dilihat dari use case diagram pada gambar 2 .

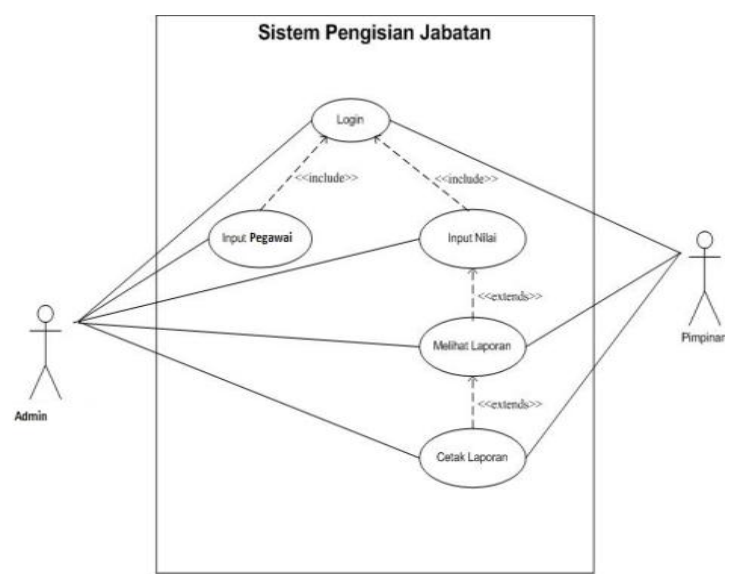

Gambar 2 Use Case Diagram Pengisian Jabatan.

\section{HASIL DAN PEMBAHASAN}

\subsection{Hasil}

Pada sistem yang diusulkan ini menggambarkan tiga entity, yaitu entity Admin, SPK dengan AHP dan Pimpinan. Seorang admin dapat masuk dengan mengisikan username dan password yang benar untuk dapat masuk ke dalam sistem. Setelah masuk sistem, admin mengisi data pegawai yang kemudian akan disimpan di database dan digunakan kembali untuk melakukan proses perhitungan nilai berdasrkan metode AHP. Admin dapat mencetak laporan penilaian pegawai dan dapat memberikan laporan tersebut kepada pimpinan.

\subsection{Aplikasi Program}

Perancangan aplikasi Pengisian Jabatan dengan metode AHP ini terdiri dari beberapa tampilan, sehingga program akan dengan mudah melakukan proses pengolahan data. 


\section{Form Login}

Form Login ini terdapat ada dua texboxt masukan yaitu User ID dan Password. User terlebih dahulu memasukkan User ID dan Password terlebih dahulu jika ingin mengakses program ini dengan mengklik tombol masuk. Adapun tampilan Loginnya bisa dilihat pada Gambar 3.

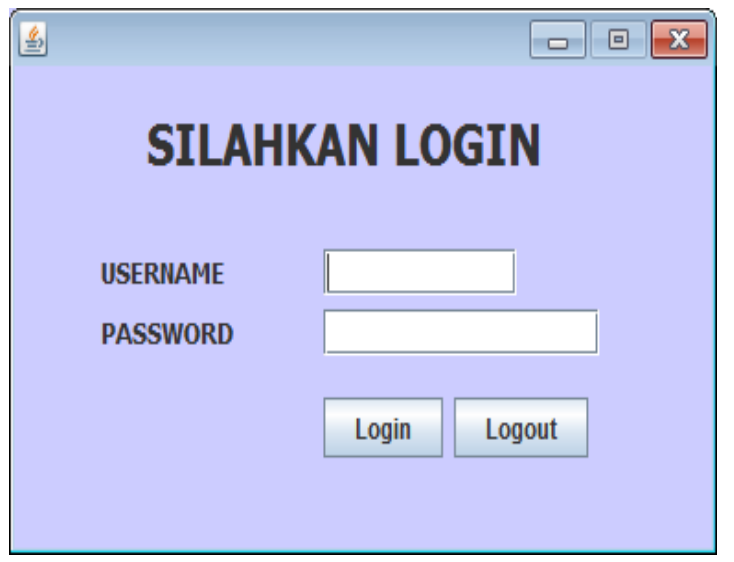

Gambar 3 Form Login.

\section{Form Tampilan Menu Utama}

Form tampilan menu utama ini terdapat beberapa menu lainnya yang dapat digunakan dalam memproses pengolahan data, seperti Menu Master, Menu Transaksi dan Menu Laporan. Adapun tampilan Menu Utama dapat dilihat pada Gambar 44.

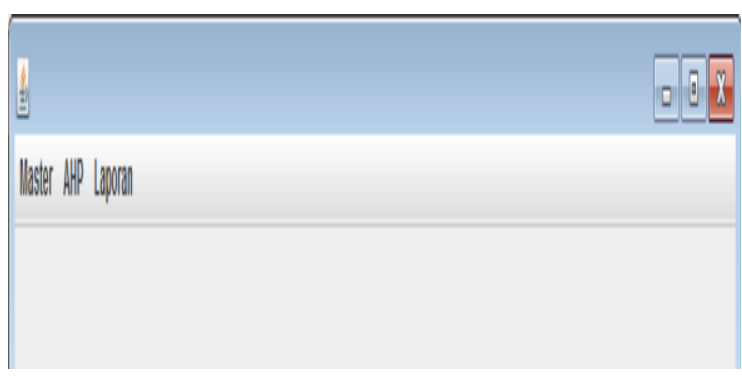

Gambar 4 Form Menu Utama.

\section{Form Menu Master Pegawai}

Pada form ini merupakan form master pegawai yang didalamnya terdapat inputan seperti no id pegawai, nama jabatan, jabatan dan pilih jabatan. Dalam form ini sistem dapat memanipulasi data seperti pada tombol simpan data, tombol ubah data, tombol hapus data serta tombol baru dan tombol keluar.

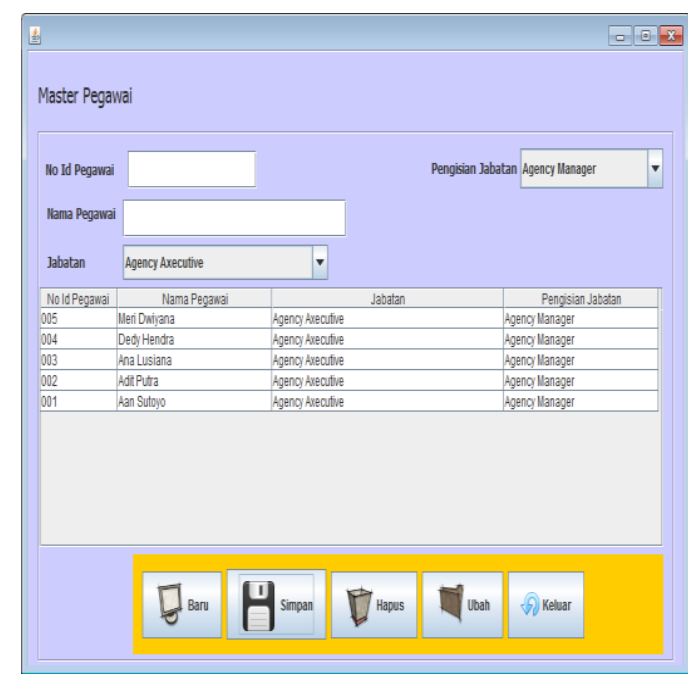

Gambar 5 Form Menu Master Pegawai.

\section{Form Menu Kriteria}

Pada form Menu Kriteria ini berfungsi untuk mengatur kriteria-kriteria berdasarkan nama kriteria penilaian yang sudah ditentukan dalam menggunakan metode AHP. Pada form ini nilainilai yang diinputkan dari kriteria-kriteria seperti kompetensi, prilaku, sikap kerja, disiplin dan prestasi kerja akan otomatis mendapatkan hasil ketika mengklik tombol AHP dan akan mendapat status konsistensi terhadap hasil proses penilaian AHP tersebut. Form menu kriteria ini dapat dilihat pada Gambar 66 sebagai berikut :

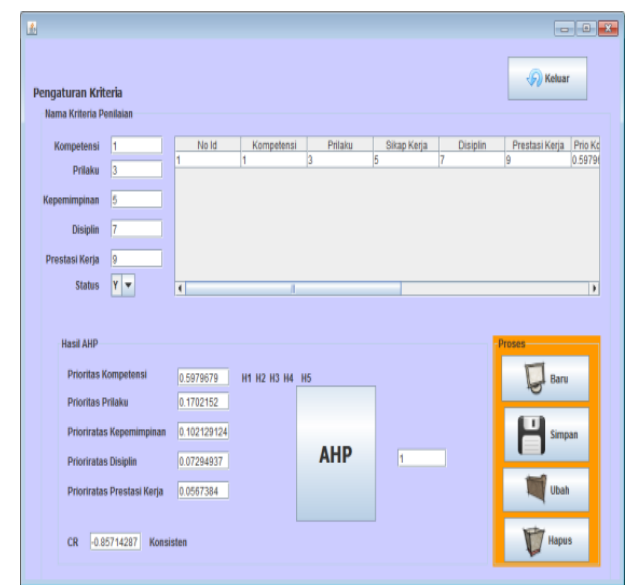

Gambar 6 Form Menu Kriteria

\section{Form Menu Penilaian Jabatan}

Pada form penilaian jabatan ini merupakan form penilaian yang akan diproses dengan metode AHP, tampilan form menu penilaian jabatan ini dapat dilihat pada Gambar 7 sebagai berikut. 


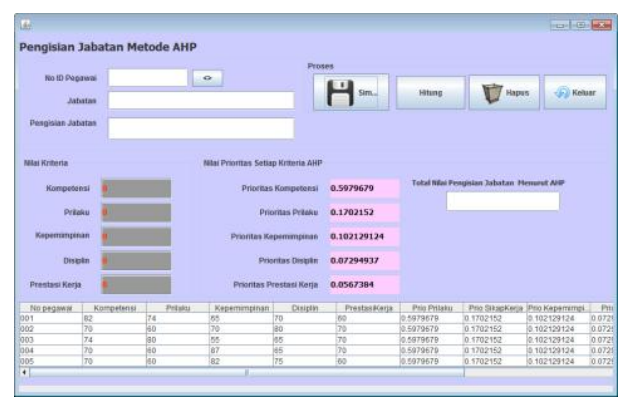

Gambar 7 Form Menu Penilaian Jabatan

Form ini terdiri dari beberapa perintah yaitu :

a. Tombol "<>" digunakan untuk masuk ke form master pegawai untuk dapat mengambil data pegawai yang akan dilakukan proses penilaian.

b. Tombol Hitung yang berfungsi untuk memproses dari nilai kriteria-kriteria yang sudah di isi untuk mendapatkan nilai prioritas setiap kriteria AHP dan untuk mengetahui total nilai pengisian jabatan menurut metode AHP.

c. Tombol simpan digunakan untuk menyimpan data setelah dilakukan pengisian nilai kriteriakriteria dan dilakukan proses perhitungan.

d. Tombol keluar untuk keluar dari form pengisian jabatan tersebut.

\section{Form View Laporan}

Menu Laporan ini berfungsi untuk melihat hasil proses perhitungan yang telah dilakukan pada beberapa pegawai yang dilakukan seleksi pengsian jabatan. Tampilan form view laporan pengisian jabatan ini dapat dilihat pada Gambar sebagai berikut.

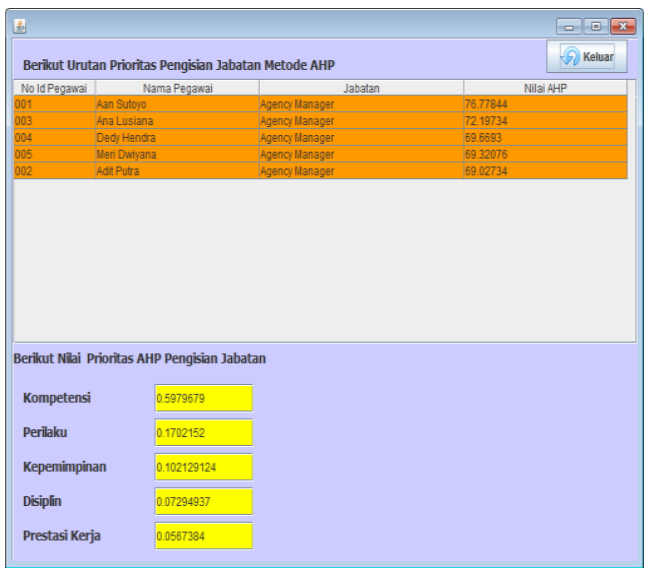

Gambar 8 Form View Laporan Pengisian Jabatan

Pada form view laporan ini kita dapat melihat nama-nama pegawai beserta nilai kriteriakriterianya yang telah diproses berdasarkan metode AHP untuk menentukan pegawai-pegawai mana yang akan menduduki jabatan-jabatan yang sesuai dengan nilai kriteria mereka.

Tabel 1 Tabel Nilai dalam AHP

\begin{tabular}{|l|c|c|c|c|c|c|}
\hline No & Nama & $\begin{array}{c}\text { Aan } \\
\text { Sutoyo }\end{array}$ & $\begin{array}{c}\text { Adit } \\
\text { Putra }\end{array}$ & $\begin{array}{c}\text { Ana } \\
\text { Lusiana }\end{array}$ & $\begin{array}{c}\text { Dedy } \\
\text { Hendra }\end{array}$ & $\begin{array}{c}\text { Meri } \\
\text { Dwiyana }\end{array}$ \\
\hline $\mathbf{1}$ & Aan Sutoyo & 7 & 5 & 4 & 6 & 5 \\
\hline $\mathbf{2}$ & Adit Putra & 6 & 7 & 6 & 7 & 7 \\
\hline $\mathbf{3}$ & Ana Lusiana & 8 & 6 & 7 & 8 & 8 \\
\hline $\mathbf{4}$ & Dedy Hendra & 6 & 5 & 5 & 5 & 6 \\
\hline $\mathbf{5}$ & Meri Dwiyana & 6 & 5 & 7 & 6 & 7 \\
\hline
\end{tabular}

Tabel 2 Hasil Pembagian Matriks Perbandingan Berpasangan Kriteria Kepemimpinan

\begin{tabular}{|l|c|c|c|c|c|c|}
\hline No & Nama & Aan Sutoyo & $\begin{array}{c}\text { Adit } \\
\text { Putra }\end{array}$ & Ama Lusiana & $\begin{array}{c}\text { Dedy } \\
\text { Hendra }\end{array}$ & Mferi Dwiyana \\
\hline $\mathbf{1}$ & Aan Sutoyo & 1 & 1.5 & 1.75 & 1.25 & 1.75 \\
\hline $\mathbf{2}$ & Adit Putra & 0.666666667 & 1 & 1.1666666667 & 0.8333333333 & 1.1666666667 \\
\hline $\mathbf{3}$ & Ana Lusiana & 0.571428571 & 0.857142857 & 1 & 0.714285714 & 1 \\
\hline 4 & Dedy Hendra & 0.8 & 1.2 & 1.4 & 1 & 1.4 \\
\hline $\mathbf{5}$ & Meri Dwiyana & 0.571428571 & 0.857142857 & 1 & 0.714285714 & 1 \\
\hline
\end{tabular}

Tabel 3 Hasil Pembagian Matriks Perbandingan Berpasangan Kriteria Prestasi Kerja

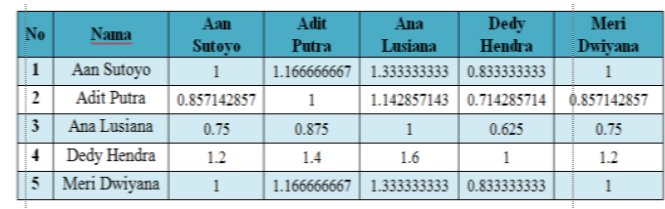

Tabel 4. Hasil Normalisasi Matriks Perbandingan Berpasangan Kriteria Prestasi Kerja

\begin{tabular}{|c|c|c|c|c|c|}
\hline Nama & $\begin{array}{c}\text { Aan } \\
\text { Sutoỵ }\end{array}$ & Adit Putra & $\begin{array}{c}\text { Ana } \\
\text { Lusiana }\end{array}$ & $\begin{array}{c}\text { Dedy } \\
\text { Hendra }\end{array}$ & $\begin{array}{c}\text { Meri } \\
\text { Dwiyana }\end{array}$ \\
\hline Aan Sutoyo & 0.116861436 & 0.117969244 & 0.116014087 & 0.106302202 & 0.110410095 \\
\hline Adit Putra & 0.100166945 & 0.101116495 & 0.099440646 & 0.091116173 & 0.094637224 \\
\hline Ana Lusiana & 0.087646077 & 0.088476933 & 0.087010566 & 0.079726651 & 0.082807571 \\
\hline Dedy Hendra & 0.140233723 & 0.141563092 & 0.139216905 & 0.127562642 & 0.132492114 \\
\hline Meri Dwiyana & 0.116861436 & 0.117969244 & 0.116014087 & 0.106302202 & 0.110410095 \\
\hline
\end{tabular}

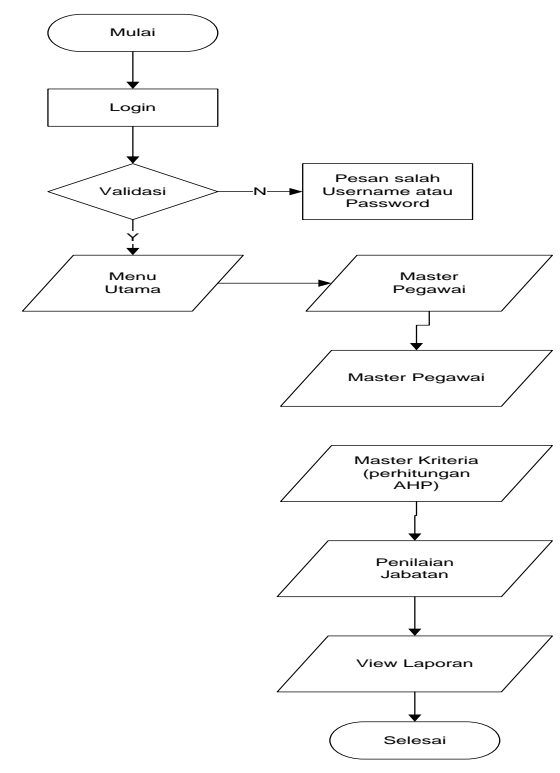

Gambar 9 Basis implementasi sistem penentuan Pengisian Jabatan 
di PT.Life Assurance Bandar Lampung.

\subsection{Hasil Pengamatan Sebelum Implementasi (Pre-Test)}

Hasil nilai dari kuesioner yang diberikan pada Staf HRD untuk pre-test adalah sebagai berikut:

Tabel 5 Hasil Pengamatan

Sebelum Implementasi (Pre-Test)

\begin{tabular}{|c|c|c|c|c|c|c|}
\hline \multirow[b]{2}{*}{ No } & \multirow[b]{2}{*}{ Nama } & \multicolumn{4}{|c|}{ Pertanyaan } & \multirow[b]{2}{*}{ Nilai } \\
\hline & & $\begin{array}{c}1 \\
\text { (kwrang) }\end{array}$ & $\begin{array}{c}2 \\
\text { (cukup) }\end{array}$ & $\begin{array}{c}3 \\
\text { (sesuai) }\end{array}$ & $\begin{array}{c}4 \\
\text { (sangat } \\
\text { sesuai) }\end{array}$ & \\
\hline 1 & \begin{tabular}{|l|} 
Gufran \\
\end{tabular} & 1 & 1 & 1 & 2 & 5 \\
\hline 2 & Jen & 1 & 1 & 1 & 1 & 4 \\
\hline 3 & Ratih & 1 & 1 & 1 & 1 & 4 \\
\hline
\end{tabular}

\subsection{Hasil Pengamatan Setelah Implementasi (Post-Test)}

Setelah diterapkan perangkat lunak, berikutnya disebar kuisioner tahap kedua untuk mengukur pengaruh implementasi perangkat lunak, hasil nilai dari kuesioner yang diberikan adalah sebagai berikut:

Tabel 6 Hasil Pengamatan Setelah Implementasi (Post-Test)

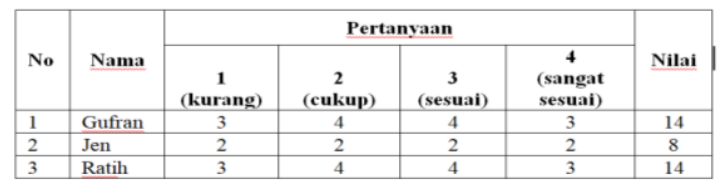

\subsection{Implikasi Penelitian}

Dari hasil kuisoner diatas, maka t hitung akan dibandingkan dengan $\mathrm{t}$ tabel. Jika perbedaannya signifikan, maka disimpulkan bahwa hipotesa diterima. Dari data hasil pre test dan post test yang telah dilakukan sebelumnya, dapat diringkas menjadi tabel berikut ini.

Tabel 7 Implikasi Penelitian

\begin{tabular}{|l|l|l|l|}
\hline No & Nama & Pre-Test & Post-Test \\
\hline 1 & Gufran & 5 & 14 \\
\hline 2 & Jen & 4 & 8 \\
\hline 3 & Ratih & 4 & 14 \\
\hline \multicolumn{2}{|l}{ Total Nilai } & $13 / 3=4.33$ & $32 / 3=10.66$ \\
\hline
\end{tabular}

Setelah dilakukan Pre-Test dan Post-Test terhadap system, dapat disimpulkan bahawa nilai setelah aplikasi diimplementasikan (Post-Test) ternyata lebih tinggi yaitu: 10.66 .

\section{KESIMPULAN DAN SARAN}

\subsection{Kesimpulan}

Berdasarkan dari hasil penelitian, analisis dan perancangan sistem pengisian jabatan dapat ditarik kesimpulan yaitu :

1. Penelitian sistem pengisian Jabatan bisa dijadikan dasar pengambilan keputusan, secara Objektif yang dapat dipertanggungjawabkan dengan dukungan perhitungan yang dilakukan dengan Analytic Hierarchiy Process (AHP) sebagai model sistem pendukung keputusan dengan Perbandingan tingkat Akurasi penggunaan Metode Analytic Hierarchiy Process (AHP) sebagai model sistem pendukung keputusan untuk pengisian jabatan dengan nilai akurasi yaitu $99,9662 \%$ Di bandingkan perhitungan secara manual.

2. Aplikasi Sistem Pendukung Keputusan Pengisian Jabatan menggunakan Metode Analytic Hierarchiy Process (AHP) dapat digunakan untuk membantu dalam pengisian Jabatan.

\subsection{Saran}

Dari permasalahan-permasalahan yang ada khususnya dalam hal menjalankan program sistem pendukung keputusan pengisian jabatan, maka peneliti mengajukan beberapa saran yaitu :

1. Pengembangan lebih lanjut menjadi sistem pengisian jabatan berbasis web sehingga pengambil keputusan bisa online dimanapun mereka berada.

2. Diharapkan peneliti berikutnya menggunakan metode lain selain Analytic Hierarchiy Process $(A H P)$.

\section{DAFTAR PUSTAKA}

[1] Kusrini. (2007). Konsep dan Aplikasi Sistem Pendukung Keputusan. Yogyakarta.: ANDI.

[2] Munawar. (2005). Pemodelan Visual dengan $U M L$. Yogyakarta: Graha Ilmu.

[3] Saaty. (1993). Pengambilan Keputusan Bagi Para Pemimpin, Proses Hirarki Analitik untuk Pengambilan Keputusan dalam Situasi yang Kompleks. Jakarta: Pustaka Binama Pressindo.

[4] Sugiyono. (2010). Metode Penelitian Kuantitatif Kualitatif RND. Bandung: Alfabeta.

[5] Suryadi, K. d. (2002). Sistem Pendukung Keputusan: Suatu Wacana. Bandung: Remaja Rosdakarya. 


\title{
Template Penulisan Jurnal Expert
}

\author{
First Author ${ }^{\# 1}$, Second Author ${ }^{* 2}$, Third Author ${ }^{\# 3}$ \\ ${ }^{\#}$ First-Third Department, First-Third University \\ Address Including Country Name \\ ${ }^{1}$ first.authorefirst-third.edu \\ ${ }^{3}$ third.authorefirst-third.edu \\ *Second Company \\ Address Including Country Name \\ ${ }^{2}$ second. authoresecond. com
}

\section{Abstrak}

Abstrak dalam bahasa Indonesia ditulis dengan rata kiri-kanan, dengan satu spasi dan satu kolom. Kata "Abstrak" sebagai judul ditulis dalam huruf Times 11-point, tebal, rata tengah, dengan huruf pertama dikapitalkan. Teks abstrak ditulis dengan huruf Times 10-point, satu spasi, sampai lebih kurang 150 kata. Sesudah abstrak tuliskan kata kunci dari makalah tersebut dalam daftar kata kunci. Kemudian dilanjutkan dengan teks utama makalah.

Kata kunci : : kata kunci abstrak

\section{Pendahuluan}

Semua makalah ditulis dalam bahasa Indonesia. Panduan penlisian ini dilengkapi dengan deskripsi huruf, spasi, dan informasi lainnya yang berhubungan dengan penulisan makalah anda. Diharapkan semua penulis dapat mengikuti template yang disediakan dan jika terdapat pertanyaan, silahkan menghubungi editor jurnal EXPERT di journal.expert@ubl.ac.id atau telefon +62721774626 .

\section{Format penulisan}

Materi yang akan dicetak, meliputi teks, gambar ilustrasi, dan grafik harus berada dalam area pencetakan yaitu bidang kertas A4 dengan margin 2.5 $\mathrm{cm}$ di semua sisi kertas. Jangan menuliskan atau meletakkan sesuatu diluar bidang cetak tersebut Seluruh teks ditulis dalam format dua kolom dengan lebar kolom $7.5 \mathrm{~cm}$ dan jarak antar kolom $1 \mathrm{~cm}$, kecuali bagian abstrak yang dituliskan dalam format satu kolom. Seluruh teks harus rata kiri-kanan.

Template ini menggunakan format yang dianjurkan. Untuk mempermudah penulis dalam memformat makalah/jurnalnya, format ini dapat digunakan sebagai petunjuk atau format dasar penulisan.

\section{Judul utama}

Judul utama (pada halaman pertama) harus dituliskan dengan jarak margin $2 \mathrm{~cm}$ dari tepi kertas, rata tengah dan dalam huruf Times 14-point, tebal, dengan huruf kapital pada huruf pertama dari kata benda, kata ganti benda, kata kerja, kata sifat, dan kata keterangan; jangan menggunakan huruf kapital pada kata sandang, kata hubung, terkecuali jika judul dimulai dengan kata-kata tersebut. Sisakan satu 11point baris kosong sesudah judul.

\section{Nama penulis dan afiliasi}

Nama penulis dan afiliasi diletakkan ditengah dibawah judul dan dituliskan dengan huruf Times 11point, tidak tebal. Afiliasi dan email penulis dituliskan dibawahnya dengan huruf Times 10-point, miring. Penulis yang lebih dari satu orang dituliskan dalam dua atau tiga kolom, dengan afiliasi dan email masingmasing.

\section{Tipe huruf}

Huruf yang digunakan adalah turunan dari huruf Times, meliputi Times Roman atau Times New Roman. Jika tipe huruf tersebut didak tersedia pada aplikasi pengolah kata yang digunakan, usahakan untuk memilih huruf yang memiliki kemiripan sedekat mungkin dengan Times. Hindari penggunaan huruf bit-mapped. Diharapkan untuk menggunakan huruf-huruf True-type 1.

\section{Teks utama}

Ketik teks utama dengan menggunakan huruf Times 10-point, satu spasi. Jangan menggunakan dua spasi. Setiap paragraf sebaiknya memiliki panjang lebih kurang $0.5 \mathrm{~cm}$. Pastikan teks ditulis dengan rata kiri-kanan. Jangan menambahkan baris kosong di antara paragraf. Istilah dalam bahasa asing (foreign language) yang tidak dapat diterjemahkan dalam bahasa utama makalah harus dituliskan dalam huruf miring.

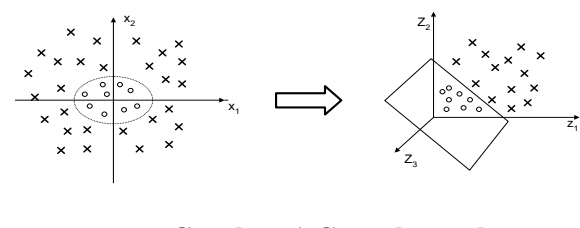

\section{Gambar 1 Contoh gambar}

Keterangan gambar dan tabel dituliskan dengan huruf Times 9-point. Sedangkan pengacuan gambar pada teks menggunakan huruf Times 10-pont. Keterangan gambar diletakkan di bawah, tengah gambar yang dijelaskan. Keterangan tabel diletakkan sebelum tabel dengan rata kiri.

Uraian yang dalam bentuk list (bulleted) dituliskan untuk:

- Uraian yang tidak memiliki aturan pengurutan tertentu

- Uraian yang tidak terikat antara uraian yang satu dan lainnya 


\begin{tabular}{|l|l|l|}
\hline No. & Jumlah & Kecepatan \\
\hline 1. & 25 & $10 \mathrm{~s}$ \\
\hline 2. & 50 & $15 \mathrm{~s}$ \\
\hline
\end{tabular}

Sedangkan untuk uraian yang berurutan dituliskan dengan penanda huruf, untuk:

a. Uraian yang memiliki aturan pengurutan

b. Uraian yang terkait dengan uraian lainnya

c. Uraian yang setiap itemnya akan diacu pada tulisan utama

\section{Judul pertama}

Sebagai contoh, "1. Pendahuluan", dituliskan dalam huruf Times 11-point, tebal, huruf pertama kata pertama ditulis dengan huruf kapital. Gunakan tanda titik (".") sesudah nomor judul.

\subsection{Judul kedua}

Sebagaimana judul pertama, judul kedua dituliskan dengan huruf Times 11-point, tebal. Nomor judul terdiri dari dua angka yang dibatasi dengan tanda titik. Tidak ada titik sesudah nomor judul dengan teks judul.

\subsubsection{Judul ketiga}

Untuk uraian yang lebih panjang dan tidak dapat dituliskan dalam bentuk uraian terurut, digunakan judul ketiga. Judul ketiga menggunakan ukuran huruf yang lebih kecil dari judul pertama dan judul kedua yaitu huruf Times 10-point, tebal. Nomor judul terdiri dari tiga angka yang dibatasi dengan tanda titik. Tidak ada titik sesudah nomor judul dengan teks judul.

\section{Catatan kaki}

Penggunaan catatan kaki dimaksudkan untuk membatu pembaca memperoleh penjelasan terhadap kalimat dalam teks tulisan utama. Catatan kaki dituliskan pada bagian bawah kolom yang memuat acuan ke catatan kaki tersebut. Catatan kaki ditulis dengan huruf Times 8-point, satu spasi. Hindari penggunaan banyak catatan kaki.

\section{Pemrograman}

Listing program dan disain algoritma dituliskan dengan menggunakan huruf dengan lebar yang tetap seperti Courier New 9-point.

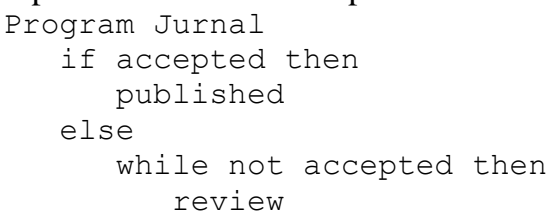

Sedangkan notasi matematika dituliskan dengan menggunakan simbol notasi yang sesuai.

\section{Daftar pustaka}

Daftar pustaka memuat daftar bacaan yang diacu dalam tulisan utama. Daftar pustaka ditulis dengan metode penulisan kepustakaan APA (American Psychological Association) Style, dengan huruf Times 10 -point. Kutipan dalam teks utama yang mengacu kepada daftar pustaka dituliskan dengan angka dalam kurung siku [nama penulis, tahun].

[1] A.B. Smith, C.D. Jones, and E.F. Roberts, Article Title, "Journal", Publisher, Location, Date, Years, pp. 1-10.

[2] Jones, C.D., A.B. Smith, and E.F. Roberts, Book Title, Publisher, Location, Date.

[3] S. Zhang, C. Zhu, J. K. O. Sin, and P. K. T. Mok, "A novel ultrathin elevated channel lowtemperature poly-Si TFT," IEEE Electron Device Lett., vol. 20, pp. 569-571, Nov. 2016. 
Redaksi :

Pusat Studi Teknologi Informasi (PSTI). Gedung Business Center Lt 2 J. Zainal Abidin No. 26 Bandar Lampung Telp. 0721 - 774626 9 772088 " 555000

SistemInformasi@ubl.ac.id 